\title{
Evaluation of Nutrient Management Plans USING AN INTEGRATED MODELING APPROACH
}

\author{
M. A. Thomas, B. A. Engel, M. Arabi, T. Zhai, R. Farnsworth, J. R. Frankenberger
}

\begin{abstract}
Agricultural best management practices (BMPs) are implemented to abate nonpoint source (NPS) pollution. Evaluation of these conservation practices requires an approach that can account for the complexities of natural systems. The overall goal of this research was to quantify changes in nutrients reaching water sources attributable to the nutrient management portion of the Natural Resources Conservation Service (NRCS) Environmental Quality Incentives Program (EQIP) as implemented in Indiana. A modeling framework, composed of a nonpoint source pollution model (GLEAMS-NAPRA) and geographic information system (GIS), was used to estimate annual nutrient loading reduction due to nutrient management plans funded by EQIP in 2005.

The GLEAMS-NAPRA model results indicated that nutrient management plans could potentially reduce field-scale nitrate loadings to water by 33\%. At the scale of the 8-digit hydrologic unit (HUC), county and state, the estimated annual reduction in nitrate attributed to funded 2005 EQIP nutrient management plans was less than 1\%. This study also shows that a hydrologic/water quality model, such as GLEAMS-NAPRA, could potentially serve as a tool to better target nutrient management applicants while improving EQIP's resource allocation. The estimated nutrient loading reduction maps created for Indiana could aid the NRCS and other organizations in better targeting nutrient management to maximize the benefits of program resources.
\end{abstract}

Keywords. Best management practices, Nutrient losses, Geographical information systems, Modeling, GLEAMS, Nonpoint source pollution, Water quality, EQIP.

$\mathrm{T}$ The U.S. Department of Agriculture (USDA) Natural Resources Conservation Service (NRCS) has implemented numerous conservation programs and activities aimed at improving environmental quality while sustaining economic development and agricultural productivity. The Farm Security and Rural Investment Act of 2002 authorized $\$ 9$ billion for the NRCS Environmental Quality Incentives Program (EQIP) to support producers who voluntarily implement approved conservation practices. EQIP promotes the dual objectives of profitable agricultural production and environmental protection through cost-share funds and incentive payments to ranchers and producers. Practices must conform to NRCS standards as described in the Electronic Field Office Technical Guide (eFOTG).

Submitted for review in January 2007 as manuscript number SW 6834; approved for publication by the Soil \& Water Division of ASABE in August 2007.

The authors are Mark A. Thomas, ASABE Member Engineer, Graduate Student, Department of Agricultural and Biological Engineering, Purdue University, West Lafayette, Indiana; Bernard A. Engel, ASABE Member Engineer, Professor, Department of Agricultural and Biological Engineering, Purdue University, West Lafayette, Indiana; Mazdak Arabi, ASABE Member Engineer, Post Doc, Department of Agricultural and Biological Engineering. Purdue University, West Lafayette, Indiana; Tong Zhai, Post Doc, Department of Agricultural and Biological Engineering. Purdue University, West Lafayette, Indiana; Richard Farnsworth, Associate Professor, Department of Forestry and Natural Resources. Purdue University, West Lafayette, Indiana; and Jane R. Frankenberger, ASABE Member Engineer, Professor, Department of Agricultural and Biological Engineering. Purdue University, West Lafayette, Indiana. Corresponding author: Bernard A. Engel, 225 S. University St., West Lafayette, IN 47907-2093; phone: 765-494-1162; fax: 765-496-1115; e-mail: engelb@purdue.edu.
Each year, participating state NRCS offices hold a competitive signup process and encourage producers to apply for possible enrollment and funding. The state allocation of EQIP funds is guided by national and state priorities that are embedded in a scoring system to evaluate submitted applications (USDA-NRCS, 2005). Among the national priorities of EQIP is the reduction of nonpoint source pollution such as nutrients, sediments, pesticides, and excess salinity in impaired watersheds consistent with Total Maximum Daily Load (TMDL) goals (USDA-NRCS, 2005). Indiana NRCS established scoring variables to represent those national priorities.

The Indiana NRCS collaborated with Purdue University and developed E-SCORE, a secure, web-based program (http://pasture.ecn.purdue.edu/ eqip/E-SCORE_DEMO/m ain_menu.cgi) for scoring, ranking, and storing EQIP applications within Indiana. The EQIP system allocates cost-share funds and incentive payments based on resource concerns and scoring rules. Although the scoring rules change periodically, they remain subjective. The evaluation of EQIP applicants using the E-SCORE system is based on a ranking process which gives higher priorities to applicants whose proposed plans would have higher scores which, to some extent, represent environmental benefits. However, the scoring system was based on expert opinion and these environmental benefits have not been validated.

Cost-share programs, technical assistance, and education are strategies employed to promote the use of practices that will reduce nutrients and sediments, thereby abating agricultural nonpoint source pollution (Boesch et al., 2001). Over the years, the Natural Resources Conservation Services (NRCS) has implemented several conservation programs aimed at improving the environment while sustaining 
agricultural productivity and economic development. Currently there are 91 conservation practices in the eFOTGs, referenced by EQIP, that describe structural and management BMPs for livestock and non-livestock practices. The nutrient management plan (NRCS practice code 590) is one of the many EQIP BMPs available to agricultural producers. Nutrient management is defined as managing the amount, source, placement, form, and timing of the application of plant nutrients and soil amendments. The purpose of the nutrient management plan is to minimize agricultural nonpoint source pollution to surface and ground water sources and to maintain or improve the chemical, biological, and physical structure of the soil (USDA-NRCS, 2005).

In the Midwestern United States, arable lands are commonly used for the production of corn and soybeans. Generally, commercial fertilizer is used to enhance or sustain profitable crop production. Producers often apply more than the required amount of fertilizer in order to attain higher yields, which may translate to increased revenues. Excessive fertilization of agricultural lands often results in pollution of water sources via runoff, leaching and sediment transfer. Pollution from Midwest agricultural fields contributes to the contamination of surface and ground water sources as well as hypoxia in the Gulf of Mexico (Bakhsh and Kanwar, 2001; Power et al., 2001). These increasing environmental concerns have caused researchers and federal agencies to focus on altering the rate of chemical input usage in agriculture as a passive method for environmental improvement (Hertel et al., 1996).

\section{ОвJECTIVES}

The overall goal of this research was to quantify changes in nutrients reaching surface water and shallow ground water sources for the Indiana participants in the nutrient management portion of the NRCS EQIP. The estimates of nutrient loading reductions were used to address the research questions: What are the estimated spatial variations in nutrient loadings across the state of Indiana from cropped areas? What are the field-scale, watershed-scale, county level, and state reductions in nitrate loadings by implementing the 2005 EQIP funded nutrient management plans? Were 2005 EQIP applicants selected for funding in the regions where the nitrate loading reduction would be the greatest? Would there be additional nitrate loading reductions by targeting EQIP nutrient management plan applicants based on hydrologic/water quality model results?

\section{Modeling Best Management Practices}

Computer models represent an intermediate step in understanding changes in nonpoint source levels and may be useful in improving EQIP's resource allocations, prior to any in-field monitoring. The use of computer models to forecast naturally occurring conditions (e.g., daily precipitation and hurricane paths) have become prevalent in the decision-making process of today's society. Models have been proven valuable in cases where data are limited or unavailable (Tim, 1996). Computer simulation can reduce time, is relatively inexpensive, and is an environmentally safe technique to evaluate the effects of agricultural management practices on surface and subsurface water sources (Mahmood et al., 2002).
Numerous computer models, with applications for agriculture, have been developed to predict pollutants such as pesticides, fertilizers, and sediments reaching regional surface and subsurface water sources. Traditionally, the models are used to evaluate the impact of BMPs such as grassed waterways, filter strips, and buffer strips at field- and watershed-scales (e.g., Vaché et al., 2002). Researchers have used models such as Groundwater Loading Effects of Agricultural Management Systems (GLEAMS) (Leonard et al., 1987), Soil Water Assessment Tool (SWAT) (Arnold et al., 1998), and Environmental Policy Integrated Climate (EPIC) (Williams et al., 1990) to simulate the environmental impacts of management and structural best management practices (Arabi et al., 2006).

The GLEAMS model was selected to perform water quality simulation of agricultural BMPs due to the modeling scale (statewide), research time-frame, and the model's broad-scale batch run capabilities. The GLEAMS model was developed to simulate the edge-of-field and bottom-of-root-zone loadings of water, sediment, pesticides, and plant nutrients (Leonard et al., 1987). Hydrology, erosion, nutrient, and pesticides are four major components of the GLEAMS model. The model incorporates various hydrological processes, such as infiltration, runoff, soil evaporation, plant transpiration, rainfall/irrigation, snow melt, and soil water movement within the root zone (Leonard et al., 1987). GLEAMS can be used to perform regional simulations by dividing regions into smaller "representative" fields based on National Agricultural Statistics Service (NASS) land use data (Lim and Engel, 2003). The plant nutrient component of GLEAMS considers the complexity of the nitrogen and phosphorus cycles. The model accounts for daily, monthly or yearly nitrate-nitrogen and ammonia-nitrogen loadings to surface runoff, leached and bound to sediments (Knisel and Davis, 2000). Complex models such as GLEAMS have been used in conjunction with GIS to retrieve and manipulate data to new formats (Lim, 2001).

The National Agricultural Pesticide Risk Analysis (NAPRA) model was extended and now includes a nutrient component (Lim and Engel, 2003). The NAPRA model uses GLEAMS as the core model to simulate nutrient loadings and can perform simulations for county or watershed areas for nutrient loadings to surface and shallow ground water (Bagdon et al., 1994; Lim and Engel, 2003). The postprocessor of the NAPRA model aggregates and converts GLEAMS output into time series data which can be externally linked to GIS layers associated with STATSGO soil units to display spatial information.

\section{MethodologY}

The methodology employed to evaluate the water quality benefits of the funded 2005 EQIP non-livestock nutrient management practices throughout Indiana is outlined in figure 1 . The modeling framework is composed of a nonpoint source model (GLEAMS-NAPRA), a GIS interface, and data (climatic, soil, and management) to estimate nutrient loadings to surface and shallow ground water. The 


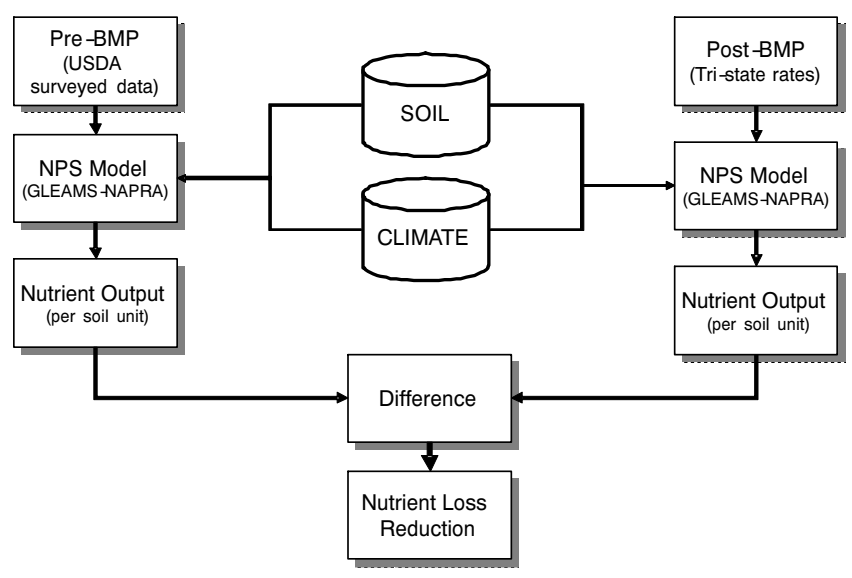

Figure 1. GLEAMS-NAPRA modeling approach for estimating EQIP nutrient loading reduction. Tri-state rates are recommended fertilizer application rates for corn in Indiana, Ohio and Michigan (Vitosh et al., 1995; USDA-NRCS, 2006).

GLEAMS-NAPRA model was applied to estimate statewide nutrient loadings to surface water and shallow ground water before and after implementation of nutrient management plans (NRCS practice code 590). Numerous scenarios were simulated based on varying fertilizer application rates. In the pre-BMP scenario, nutrient application rates were based on 5 years of USDA-surveyed field data throughout Indiana (USDA-ERS, 1990-1995). This represented the baseline scenario or pre-best management practices for nutrient application. In the post-BMP scenario, nutrient application rates were based on Indiana extension recommendations (Tri-State fertilizer recommendation; Vitosh et al., 1995) associated with crop potential yields. The difference in the scenarios was used to estimate the field-scale water quality benefits of implementing nutrient management plans (fig. 1).

\section{Climate Data}

Continuous daily precipitation and temperature, required climatic inputs for the GLEAMS-NAPRA model, were generated by the modified Climate Generator (CLIGEN-v5) (Nicks et. al, 1995) for Marion County, Indiana (center of state). CLIGEN, a stochastic weather generator, has been proven adequate in generating daily precipitation and temperature from observed historical data associated with weather stations (Elliot and Arnold, 2001; Yu, 2002; Zhang and Garbrecht, 2003). In all model simulations, the same long-term precipitation and temperature data generated for a 60-year period were used.

\section{SOILS DATA}

The STATSGO (1:250,000) soil database (USDA-NRCS, 1995) was used to obtain required properties of Indiana soil. STATSGO soils are composed of map unit identifiers (muids), each of which has a set of up to 21 components (USDA-NRCS, 1995). The components contain physical and chemical properties' data for each soil unit. The GLEAMS-NAPRA model simulated nutrient loading to the edge-of-field or bottom-of-root-zone for each of the components. Simulated results for each component were aggregated by a weighted approach to obtain output values for each STATSGO soil unit.

\section{MANAGEMENT INPUTS}

Table 1 shows the agricultural management inputs used to simulate nutrient loadings. Thomas (2006) provides details on the method used to obtain application rates corresponding to the $90^{\text {th }}$ percentile distribution $\left(222 \mathrm{~N} \mathrm{~kg} / \mathrm{ha}\right.$ and $125 \mathrm{P}_{2} \mathrm{O}_{5}$ $\mathrm{kg} / \mathrm{ha}$ ) of fertilizer application rates for Indiana producers. Nitrogen application rates of $222 \mathrm{~N} \mathrm{~kg} / \mathrm{ha}$ on corn were generally considered high and were likely to increase the nitrate levels in surface and shallow ground water (Brouder et al., 2005). Based on the assumption that EQIP provided support primarily to producers that over-apply commercial fertilizers, analyses of EQIP nutrient management plans were focused at the nitrate reduction for higher baseline application rates.

Planting, harvesting, and maturity dates were based on the typical median dates from the Indiana Agricultural Statistics Report (Indiana Agricultural Statistics, 2000-2004). Cropping management input data, such as planting date, harvesting date, maturity date, method of fertilizer application, fertilizer type, and tillage method were the same for both the pre- and post-BMP scenarios. Corn-soybean rotation was the cropping system used since it was the dominant rotation of Indiana agricultural producers, as indicated by analysis of NASS data (2002-2004). The crop rotation used in the model was corn in one-year followed by soybean the next year.

To represent the general pre-BMP behavioral practice of Indiana producers eligible for EQIP nutrient management plan implementation, application rates in model simulations were not adjusted for added nitrogen from soybeans in crop rotation systems. This representation was based on responses to a question posed in the 1995 USDA Cropping Practices Surveys, in which $73 \%$ of Indiana producers indicated that they did not adjust fertilizer application rates when the previous year's crop was soybean. Extension recommendations in Indiana are to adjust nitrogen application when the previous year's crop was soybean.

Post-BMP application rates for corn were based on extension fertilizer recommendations for Indiana (Vitosh et al., 1995), which uses the following relationship:

$$
\mathrm{N}=-27+\left(1.36 \times \mathrm{C}_{\mathrm{wy}}\right)-\mathrm{N} \text { credit }
$$

where

$\mathrm{N} \quad=$ nitrogen fertilizer application rate (lb/acre)

$\mathrm{C}_{\mathrm{wy}}=$ yield potential units (bu/acre)

Table 1. Management inputs used in GLEAMS-NAPRA simulations.

\begin{tabular}{lcc}
\hline Description & Corn Input & Soybean Input \\
\hline Planting date & 6 May & 24 May \\
Maturity date & 15 September & 10 September \\
Harvest date & 14 October & 7 October \\
Tillage & Fall chisel/spring & Fall chisel/spring disk \\
& disk & \\
Root zone depth & $76 \mathrm{~cm}$ & $76 \mathrm{~cm}$ \\
Slope length & $30 \mathrm{~m}$ & $30 \mathrm{~m}$ \\
$\begin{array}{l}\text { Nitrogen application date } \\
\text { Nitrogen application rate } \\
\text { (pre-BMP) }\end{array}$ & $5 \mathrm{May}$ & - \\
$\mathrm{P}_{2} \mathrm{O}_{5}$ application date & $22 \mathrm{~N} \mathrm{~kg} / \mathrm{ha}$ & - \\
$\mathrm{P}_{2} \mathrm{O}_{5}$ application rate & $6 \mathrm{May}$ & - \\
(pre-BMP) & $125 \mathrm{P}_{2} \mathrm{O}_{5} \mathrm{~kg} / \mathrm{ha}$ & \\
\hline
\end{tabular}


$\mathrm{N}$ credits: soybeans $=30 \mathrm{lb} / \mathrm{acre}$, grass sod $/$ pastures $=40$ $\mathrm{lb} / \mathrm{acre}$, annual legume cover crop $=30 \mathrm{lb} / \mathrm{acre}$, corn and most other crops $=0 \mathrm{lb} / \mathrm{acre}$.

Potential corn yield associated with soils, and available in the Indiana STATSGO soils database, was used to compute post-BMP fertilizer application rates. The weighted potential corn yield associated with STATSGO soils was adjusted, using a factor of 1.32, to account for development of new cultivars, improved technology and agronomic practices. This adjustment factor was determined by the ratio of expected corn yield in 2006 (based on Indiana corn grain yield trend since 1930; Nielson, 2005) and the average of weighted corn yields associated with STATSGO soil units.

Thus, the equation used to adjust corn potential yield is:

$$
\lambda=\frac{C e y}{C a w y}
$$

where

$\lambda=$ the adjustment factor for corn yield

$\mathrm{C}_{\mathrm{ey}}=$ the trend line expected yield for a given year

$\mathrm{C}_{\mathrm{awy}}=$ average of weighted corn yield of STATSGO soil units

Also, the equation used to estimate corn yield potential per STATSGO soil unit is:

$$
C w y=\frac{\sum_{i=1}^{n}\left(\text { comppct }_{i}\right)\left(\text { nirryld }_{i}\right)}{\sum_{i=1}^{n}\left(\text { comppct }_{i}\right)} \times \lambda
$$

where

$$
\begin{aligned}
& \mathrm{C}_{\mathrm{wy}} \quad=\text { the weighted potential corn yield per soil } \\
& \text { unit } \\
& \mathrm{n} \quad=\text { number of components with estimated yield } \\
& \text { per soil unit } \\
& \text { comppct }=\text { the percentage of the component of the map } \\
& \text { unit } \\
& \text { nirryld } \quad=\text { the expected yield for corn without } \\
& \text { supplemental irrigation in an average year } \\
& \text { under a high level of management. } \\
& \lambda=\text { the adjustment factor for corn yield. }
\end{aligned}
$$

It was assumed that all producers followed sound agronomic principles with regards to fertilizer timing and method of application on corn when following the nutrient management plan.

\section{Nitrate Loading Adjustments for Tile Drainage}

Numerous agricultural lands in Indiana have tile drainage systems causing nitrate leached to subsoil to be redistributed to the surface water (Kladivko et al., 2004). Water and hydrophilic compounds such as nitrates that are transported below the root zone are likely to be captured by these networks of tile drains and eventually discharge to surface waters, thus degrading water quality (Randall and Vetsch, 2005). To account for an estimate of the leached nitrate intercepted by tile drains, an adjustment factor of 0.75 was used to redirect estimated nitrate leached in soil to surface water (Adeuya et al., 2005).The equation used to estimate net nitrate to surface water is:

$$
\mathrm{NNO}_{3}=\mathrm{NO}_{3 \text { ro }}+\left(\mathrm{NO}_{3 \text { lea }} \times \mathrm{T}_{\mathrm{de}}\right)
$$

where

$\mathrm{NNO}_{3}=$ net nitrate-nitrogen to surface water $(\mathrm{kg} / \mathrm{ha})$

$\mathrm{NO}_{3 \text { ro }}=$ nitrate-nitrogen loading in surface runoff $(\mathrm{kg} / \mathrm{ha})$

$\mathrm{NO}_{3 \text { lea }}=$ nitrate-nitrogen leached to shallow groundwater $(\mathrm{kg} / \mathrm{ha})$

$\mathrm{T}_{\mathrm{de}} \quad=$ adjustment factor for tile drain

\section{COUNTY AND 8-Digit HUC ANALYSIS OF NuTRIENT \\ LOADING REDUCTION}

Model simulated results linked to STATSGO map units and Indiana agricultural lands were used to obtain nutrient loading estimates in each U.S. Geological Survey (USGS) 8-digit hydrologic unit code (HUC) and county using the GIS software ArcMap ${ }^{\text {(ix }}$ 9.1. Statistical analysis on EQIP related nutrient reduction estimates were performed external to the GIS software.

To understand whether the existing EQIP applications contributed to larger nutrient reductions, a comparison was made between EQIP applicants that were funded and applicants that were not selected for funding (hereafter referred to as unfunded EQIP plans or unfunded nutrient management plans). The funded non-livestock nutrient management applications throughout Indiana are illustrated in figure 2.The statistical significance of means in nitrate loading reduction attributed to funded and unfunded nutrient management plans were assessed using the Wilcoxon two-sample test (an appropriate alternative to the two-sample t-test for nonparametric population) (Walpole et al., 1998).

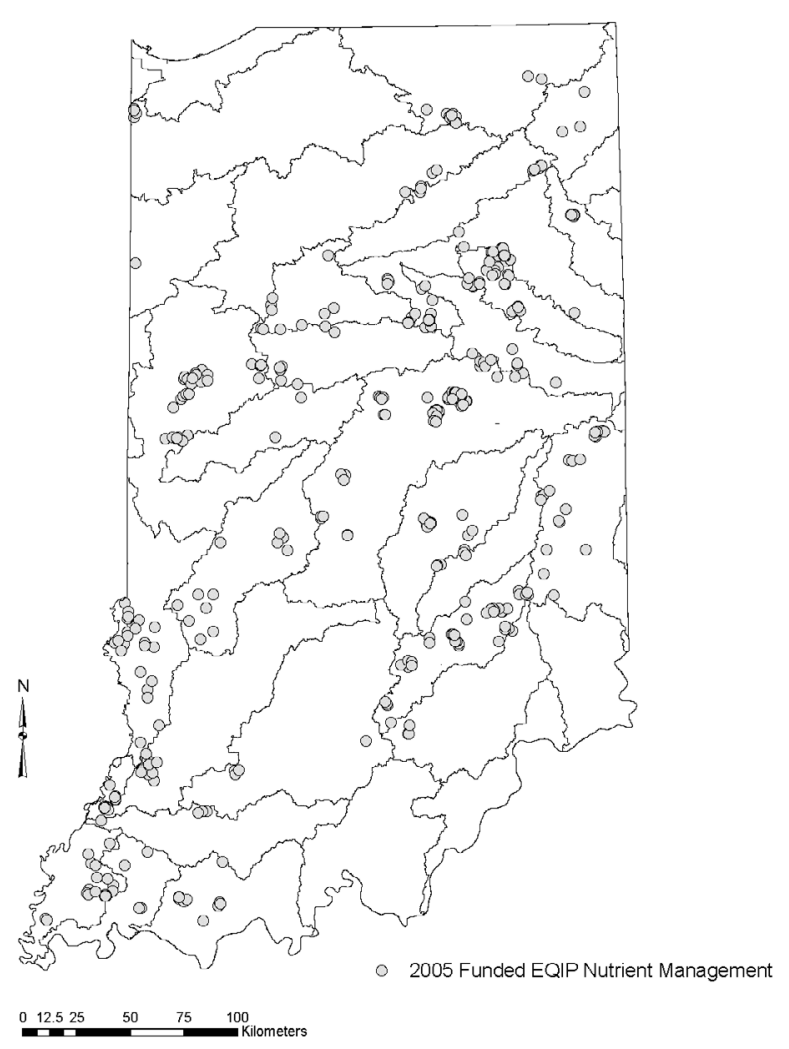

Figure 2. EQIP funded non-livestock nutrient management applications in 8-digit HUC watersheds for 2005. 


\section{Results AND Discussion}

\section{Spatial Variations in Nitrate and P LoAdings}

The estimated annual nitrate loadings to surface water ranged from $0 \mathrm{~kg} / \mathrm{ha}$ to $21.70 \mathrm{~kg} / \mathrm{ha}$ based on GLEAMS-NAPRA simulations of fertilizer application rates corresponding to the pre-BMP level (222 N kg/ha) under a corn-soybean cropping system (fig. 3).

The variability indicated in figure 3 was due to soil properties because other inputs were the same. The high estimates in nitrate loadings shown in northwest and southwest Indiana were consistent with the behavior of nitrate in Indiana soils (Adeuya et al., 2005) In 2005, scientists working with the Agricultural Research Service (ARS) on a similar project observed nitrate loadings in the range of 0.1 to $17.92 \mathrm{~kg} / \mathrm{ha}$ for the St. Joseph watershed in Indiana (Smith, personal communication, 27 July 2006). Although the simulated model results were not compared with observed data, partly due to unavailability at the model scale, the values were within the expected ranges for Indiana soils. Soils in regions of high nitrate loadings, illustrated in figure 3 , are predominantly sandy loam where high nitrate leaching was expected. However, the approach to estimate net nitrate loadings assumed that a fraction (0.75) of leached nitrates was intercepted by tile drains and redirected to surface water sources, which could potentially overestimate nitrate loadings on lands without tile drains.

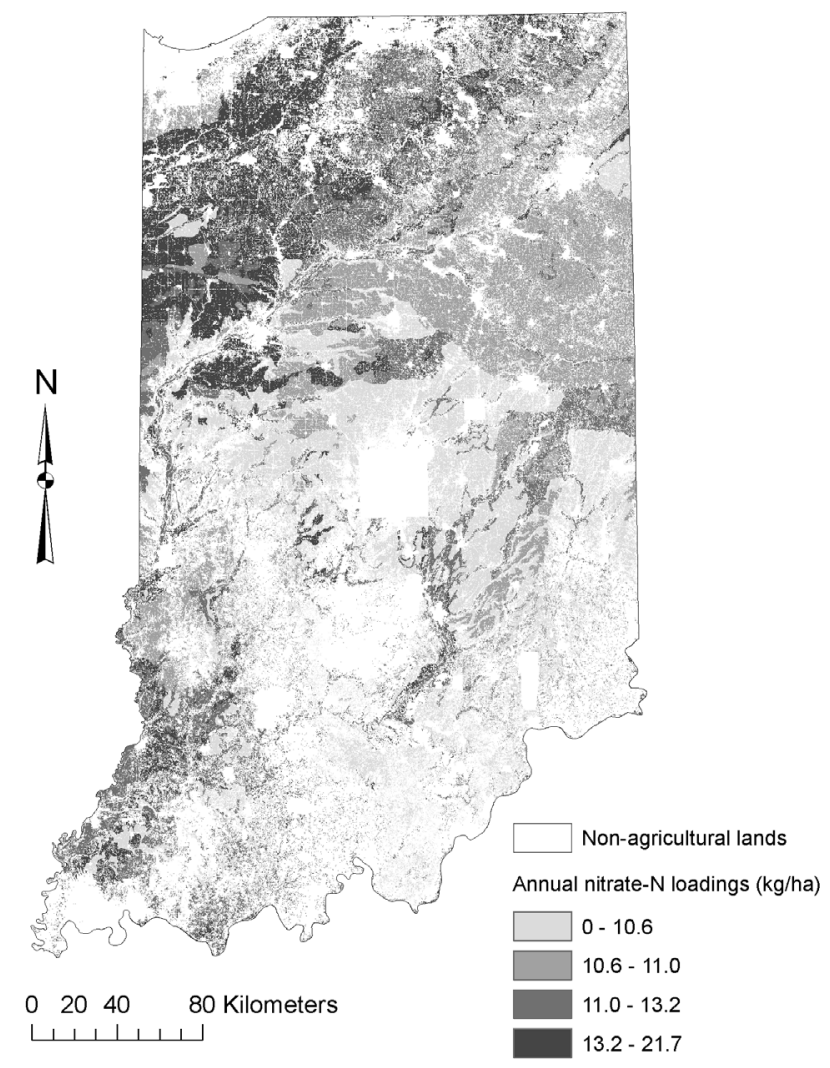

Figure 3. Median annual estimates in net $\mathrm{NO}_{3}-\mathrm{N}$ loading to surface water, under a corn-soybean cropping system, based on long-term (60-years) GLEAMS-NAPRA simulation of baseline nitrogen application rate of $222 \mathrm{~N} \mathrm{kg/ha.}$
As part of this study, $P$ loadings were also estimated before and after the application of a nutrient management plan. Estimated annual P loadings were higher than expected, based on knowledge of observed $\mathrm{P}$ loadings throughout Indiana (S. Brouder, personal communication, 4 August 2006). The model was not calibrated and validated due to the scale of our modeling efforts. Several reasons can be given for the higher-than-expected $\mathrm{P}$ loadings to surface water. First, sediment $\mathrm{P}$ accounted for most of the estimated $\mathrm{P}$ loadings in model simulations. Therefore, $\mathrm{P}$ loadings would be high if estimated erosion rates were high (Thomas, 2006). Second, sedimentation processes were not simulated. Therefore, one would expect observed P loadings to be less than simulated P loadings because a portion of eroded soils are deposited in low spots and never reach surface water. Third, studies have shown that GLEAMS often poorly represents sediment bound and leached phosphorus (Gerwig et al., 2001). Due to those limitations in modeling P, the results did not provide sufficient insight into $\mathrm{P}$ reduction potentials attributed to EQIP applications. As a result of those uncertainties in modeling $\mathrm{P}$, the results will not be discussed further in this article; however, additional details are provided by Thomas (2006).

Information obtained from measured or simulated data are usually transferred from a smaller study area to larger regions. The use of measured or simulated data without consideration of the spatial variability can be erroneous (Shirmohammadi et al., 2005). The statewide maps that display estimated annual nitrate loadings to surface water maps eliminate the need to extrapolate data from small study areas. Using these maps, program administrators could focus EQIP's efforts on the highest nutrient loading areas within Indiana. The maps with estimates in nitrate loadings could also support the EQIP state scoring system which currently uses a web-based GIS approach (known as E-SCORE: http://pasture.ecn.purdue.edu/ eqip/E-SCORE_DEMO/mai n_menu.cgi). Instead of assuming that all nutrient management applicants could provide equal water quality improvements, the maps with estimates in nutrient loadings would be used as overlays and, as such, create distinctions among nutrient management applicants.

\section{Nitrate LOAding Reduction}

The simulation results suggested that long-term, under pre-BMP conditions, $11.7 \mathrm{~kg} / \mathrm{ha}$ was the average field-scale nitrate loading attributed to nutrient management in 2005 applications funded by EQIP. Producers who followed extension recommendations for fertilizer application rates would contribute an estimated $3.89 \mathrm{~kg} / \mathrm{ha}$ in reduced annual nitrates. Thus, at the field scale, EQIP-funded applications provided an estimated $33 \%$ reduction in $\mathrm{NO}_{3}-\mathrm{N}$ loading to water sources.

Figure 4 conveys the spatial results of field-scale estimates in annual nitrate loading reductions from Indiana agricultural lands, based on long-term (60 years) model simulations. Considering the variations in soils, the nitrate loading reductions were expected to vary spatially. These maps clarified the degree of variation, in estimated annual nutrient loading reductions, that would occur under the given management inputs, soils, and climatic conditions. 


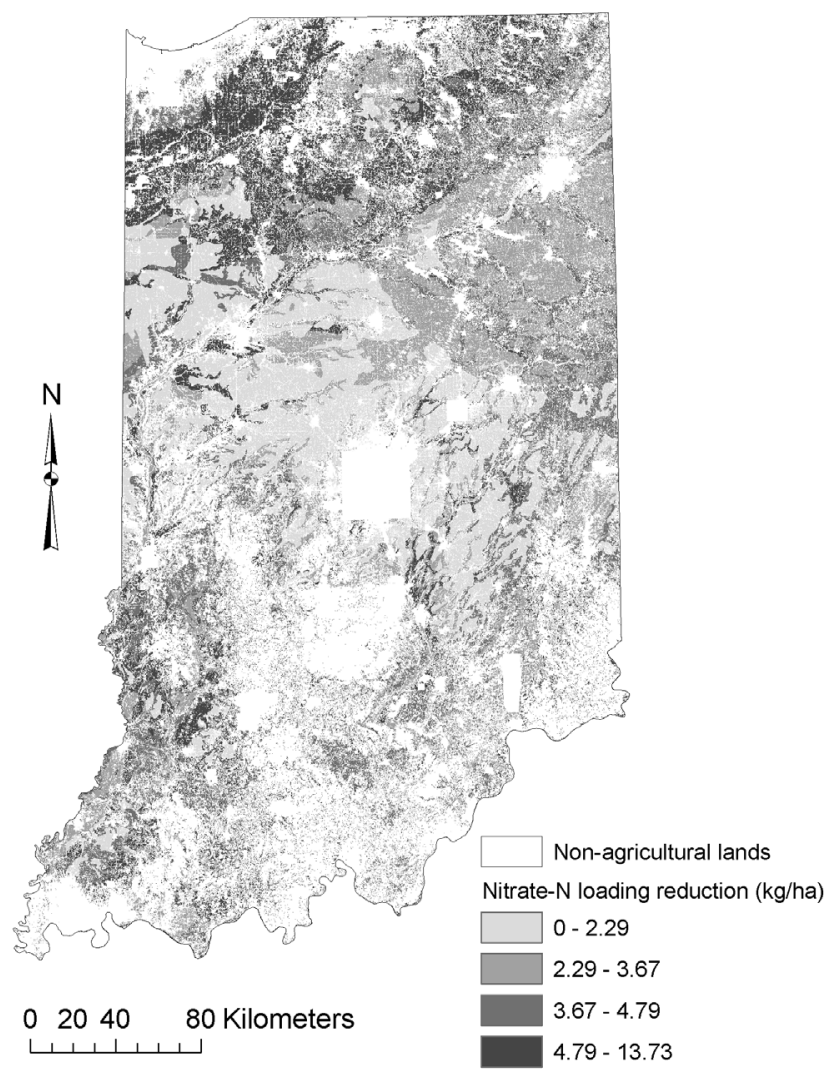

Figure 4. Differences in median annual net $\mathrm{NO}_{3}-\mathrm{N}$ loading to surface water between a baseline application rate of $222 \mathrm{~N} \mathrm{~kg} / \mathrm{ha}$ and Tri-state recommended rates, under a corn-soybean rotation cropping system on agricultural lands.

Results, which are presented in figure 5, suggest that the funded EQIP tracts have very little impact at the 8-digit HUC level. Figure 6 shows the spatial locations of the top-10 Indiana 8-digit HUC that potentially benefited from funded EQIP nutrient management programs. The decrease in nitrate loadings associated with the implementation of Tri-state recommendations, though sometimes large at the field level, amount to less than $1 \%$ of loadings within the 8-digit HUCs.

Figure 7 indicates the impact of the 2005 EQIP non-livestock nutrient management plans on top-10 Indiana counties. The spatial location of these counties is indicated by figure 8 . The counties with the highest estimates in nitrate loading reduction also had the highest number of funded non-livestock nutrient management contracts in 2005. The estimated reductions achieved suggest that the funded 2005 nutrient management tracts would not have much effect on water quality improvements. Estimated annual nitrate loading reductions attributed to EQIP plans within the counties were less than $1 \%$ of baseline loadings (Thomas, 2006).

The statewide nitrate loading reduction attributed to the EQIP program was less than $1 \%$ when compared with the reduction associated with extension recommendations in Indiana (Tri-state recommendations). The current voluntary approach used by the 2005 EQIP program obtained smaller water quality improvements than were possible, because benefits could not be optimized through selection of nutrient management applicants.

The 2005 EQIP program may have contributed to this result for several reasons. First, EQIP is voluntary. There is no guarantee that producers who want to participate also have the highest nitrate loading potential soils. Second, applicants only received incentive payments for the first 100 hectares covered by a nutrient management plan, and applicants seldom commit more land than required. Third, nutrient management addresses only a subset of the concerns that ultimately determine who is accepted in the program. Fourth, a widely dispersed program can be expected when program acceptance is determined by benefit-cost criteria (Khanna et al., 2003; Yang et al., 2005; Thomas, 2006). Therefore, the water quality impact of funded applications was further diminished due to scattered selection throughout Indiana (see fig. 2) (Thomas, 2006). This is the consequence of EQIP's effort to impact wider regions and not concentrating efforts to priority areas where benefits could be maximized.

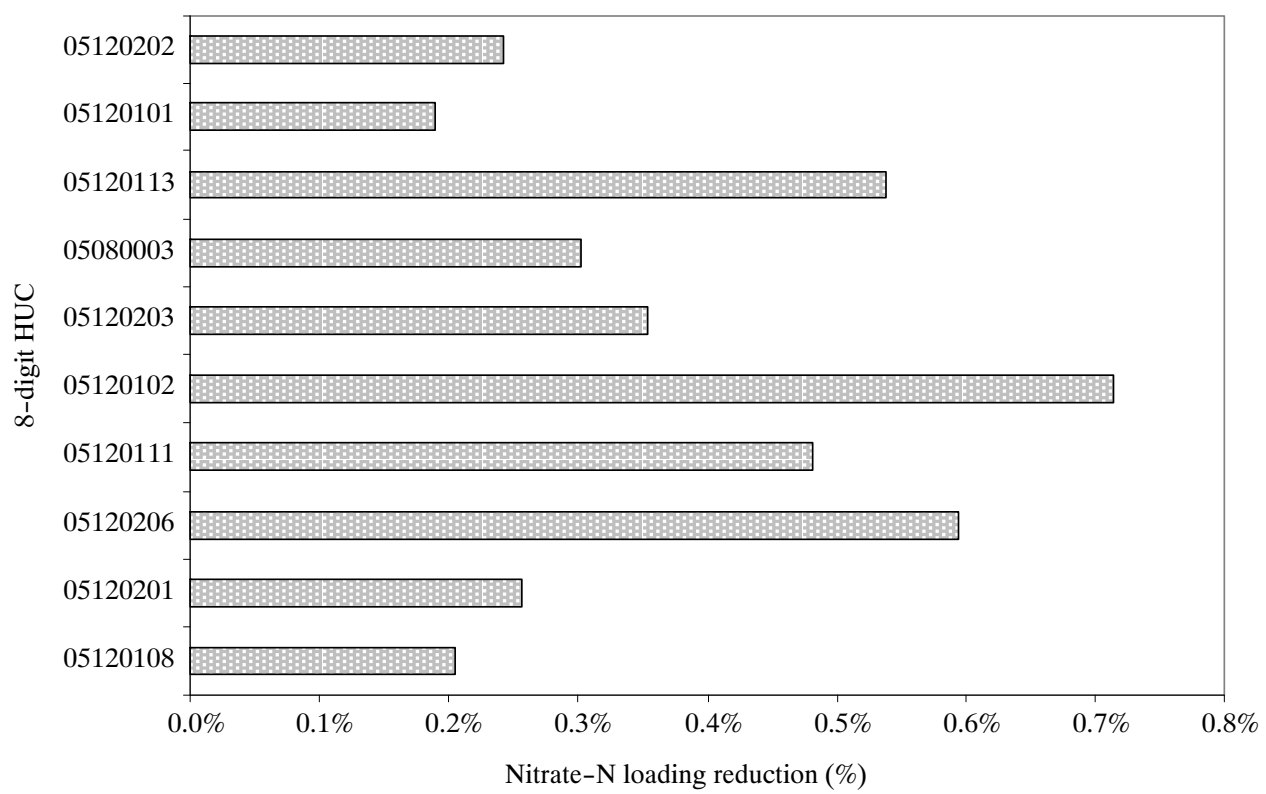

Figure 5. Estimated $\mathrm{NO}_{3}-\mathrm{N}$ loading reduction attributed to EQIP funded nutrient management programs in top-10 Indiana 8-digit HUCs. 


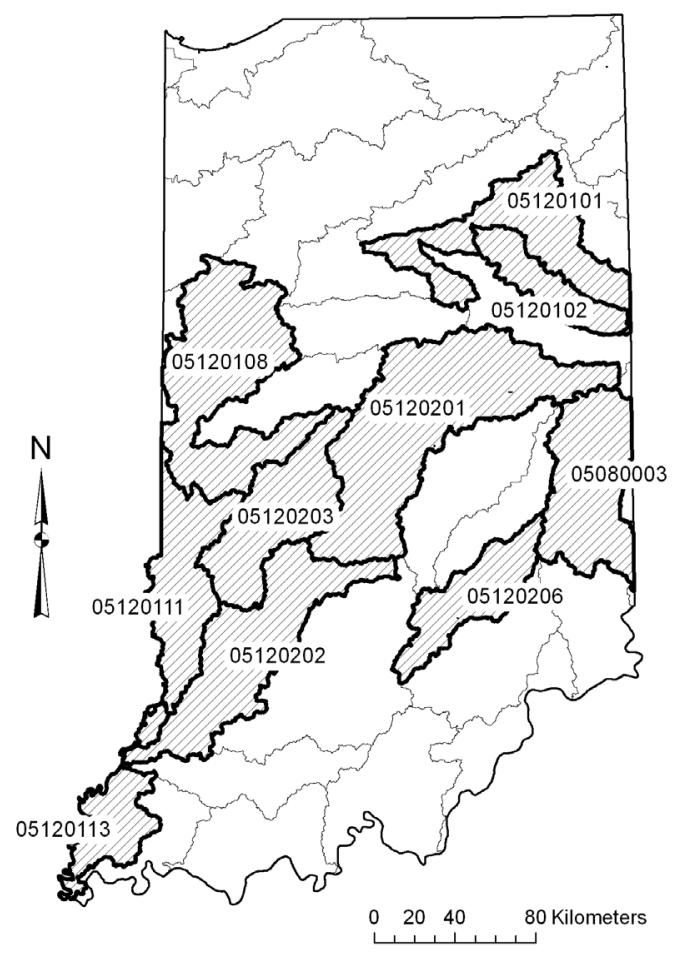

Figure 6. Location of top-10 8-digit HUCs, in Indiana, where nitrate-N was reduced by EQIP funded nutrient management programs in $\mathbf{2 0 0 5}$, based on GLEAMS-NAPRA model results. However, estimated reductions were less than $1 \%$ of loadings within 8-digit HUCs.

\section{COMPARISON OF FUNDED AND UNFUNDED EQIP APPLiCATIONS}

The third question addressed by this research was: Were 2005 EQIP applicants selected for funding in the regions where the nutrient loading reductions would be the greatest?
This question was geared towards investigating water quality improvements from 2005 funded plans as opposed to unfunded plans. Tri-state recommendations reduced nitrate loadings an average of $3.89 \mathrm{~kg} / \mathrm{ha}$ for the $2005 \mathrm{EQIP-funded}$ plans, and $4.19 \mathrm{~kg} / \mathrm{ha}$ for the unfunded plans in 2005 . The null hypothesis - no difference in nitrate loading reductions between funded and unfunded EQIP plans - was not rejected at an alpha level of 0.05 (Walpole et al., 1998). Although nutrient management is one component in a complex selection process, this result suggests the selection process used by NRCS within E-SCORE was ineffective in identifying the best tracts to fund for non-livestock nutrient management plans.

\section{Targeting Areas for Additional Nitrate LoAding REDUCTION}

Analysis of model results indicated that at the state level the total reduction in nitrates attributed to the existing 2005 EQIP program equaled $62,075 \mathrm{~kg}$ per year. This reduction could have been almost quadrupled to $220,738 \mathrm{~kg}$ per year if the same acreage of EQIP-funded agricultural lands were selected from higher nitrate loading areas located throughout Indiana, as suggested by model results (fig. 4). Therefore, there were many areas throughout the state that could potentially provide greater reduction in nitrate loadings than those funded by EQIP. In Henry county, for example, the maximum nitrate loading reduction obtained from EQIPfunded applications was an estimated $2.05 \mathrm{~kg} / \mathrm{ha}$ (Thomas, 2006). Within the same county, however, there exists 31,738 ha of agricultural lands with higher annual nitrate loading reduction estimates.

The U.S. agricultural sector relies on voluntary actions of producers to abate nonpoint source pollution. Voluntary initiatives do not require or guarantee improvement in environmental performance, because they provide flexibility in the extent of improvement (Khanna, 2001). The current voluntary approach could potentially be improved by targeting nutrient management applicants in areas where nutrient loading reductions would be maximized. The

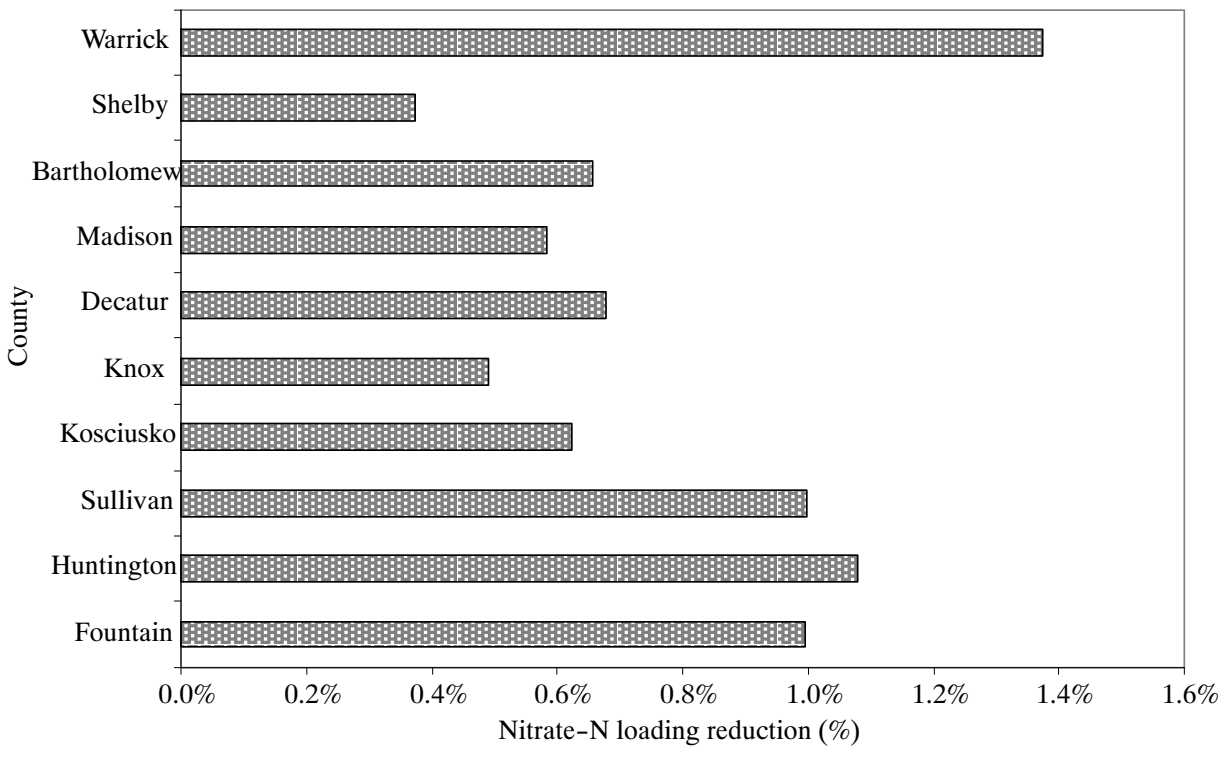

Figure 7. Estimated $\mathrm{NO}_{3}-\mathrm{N}$ loading reduction attributed to funded $2005 \mathrm{EQIP}$ programs in top-10 Indiana counties. The estimated $\mathrm{NO}_{3}-\mathrm{N}$ reduction were obtained from simulated baseline application rate of $222 \mathrm{~N} \mathrm{~kg} / \mathrm{ha}$ compared with Tri-state recommended rates, under a corn-soybean cropping system. 


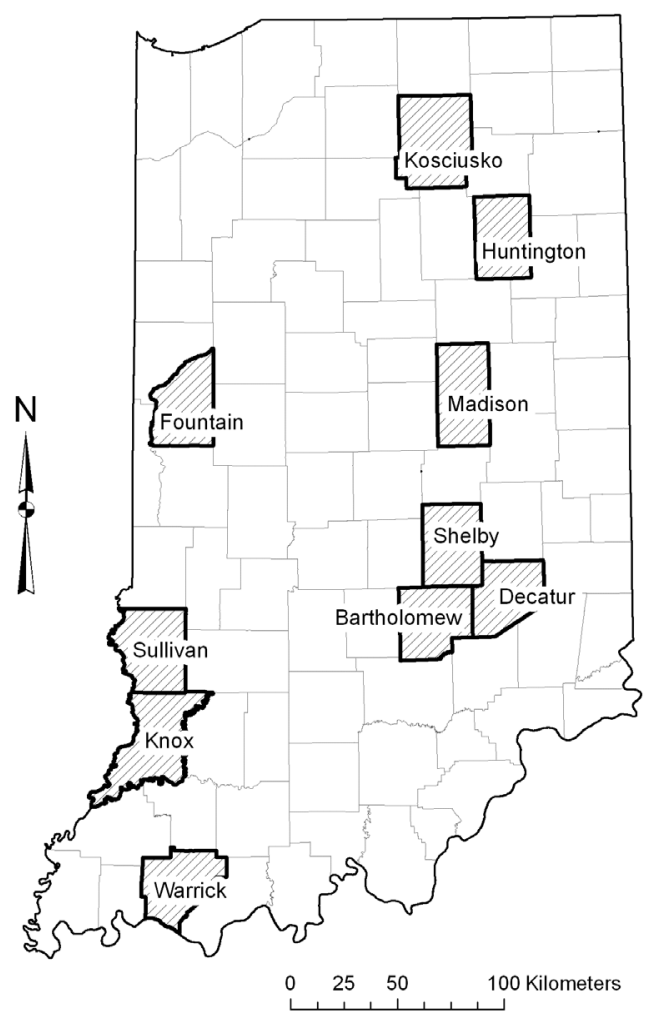

Figure 8. Location of top-10 Indiana counties where nitrate-N was reduced by EQIP funded nutrient management programs in 2005 , based on GLEAMS-NAPRA model results. However, estimated reductions were less than $1 \%$ of loadings within counties.

Indiana EQIP program could better support national efforts to abate nonpoint source pollution from agricultural fields by allocating resources to producers in high risk areas (based on hydrologic/water quality model results).

\section{Conclusions}

The overall goal of this research was to quantify changes in nutrients reaching water sources attributable to the nutrient management portion of the Natural Resources Conservation Service (NRCS) Environmental Quality Incentives Program (EQIP) as implemented in Indiana. As expected, spatial variations in soils influenced changes in nutrients reaching water sources. Soils in southwest and northwest Indiana made these areas prone to relatively high nitrate loadings from agricultural lands.

Results from our nonpoint source pollution simulations indicated that currently funded 2005 EQIP nutrient management plans could potentially reduce field-scale nitrate loadings to water by $33 \%$. This suggests that the recommended fertilizer application rates (Tri-state recommendations) can serve to abate NPS pollution to water sources in the state by reducing nitrate loadings to the edge-of-field. These field-level reductions, however, translated to less than a $1 \%$ decrease in nitrate loadings at the 8 -digit hydrologic unit, county and state levels. This low impact was possibly due to the voluntary nature of EQIP, the program's incentive payment limitation of 100 ha for nutrient management, other competing EQIP objectives, and benefit-cost criteria, all of which contribute to a scattering of funded applications throughout Indiana. Instead of wide disbursements of EQIP's resources throughout the State, the counties or areas within priority watersheds could receive increased funding opportunities for nutrient management. The suggested approach should produce noticeable reductions in nutrient loading at the 8-digit hydrologic unit and county level.

Statistical tests indicated that there were no significant differences in the distributed nitrate loading reduction of funded and unfunded nonlivestock nutrient management applications under the 2005 EQIP program. More research is needed to determine if other objectives of the EQIP program, the scoring mechanism, or EQIP's voluntary participation contribute to this problem.

The results of the modeled management scenario demonstrated that the EQIP program can potentially improve allocation of resources by using hydrologic/water quality models in the application selection process. The GLEAMS-NAPRA estimates for nutrient loadings were considered reasonable for Indiana. A GLEAMS-NAPRA analysis could possibly be adapted by other states. In addition, the integration of GLEAMS-NAPRA and GIS potentially serves as a powerful tool for evaluating agricultural management practices and allocating scarce Federal funds. The maps provided information on the spatial variability in nitrate loadings throughout the state and highlight opportunities for targeting high priority areas. Finally, the information acquired from the simulated estimates in nutrient loading reductions could potentially improve EQIP's accountability and serve as a water quality impact tool. The statewide data layers, with continuous variables, could be used to substitute the nonpoint source scoring component in NRCS's scoring systems such as E-SCORE.

\section{ACKNOWLEDGEMENTS}

This project was supported in part by the Natural Resources Conservation Service, through project number 68-3A75-4-174 of the Conservation Innovation Grant. The authors are appreciative of GIS support provided by Larry Theller and Derya Ozgoc in the Department of Agricultural and Biological Engineering and Department of Forestry and Natural Resources, respectively, at Purdue University, West Lafayette, Indiana.

\section{REFERENCES}

Adeuya, R. K (Mitchell)., K. J. Lim, B. A. Engel, and M. A. Thomas. 2005. Modeling the average annual nutrient losses of two watersheds in Indiana using GLEAMS-NAPRA. Transactions of the ASAE 48(5): 1739-1749.

Arabi, M., R. S. Govindaraju, M. M. Hantush, and B. A. Engel. 2006. Role of watershed subdivision on modeling the effectiveness of best management practices with SWAT. J. of the American Water Resources Association 42(2): 513-528.

Arnold, J. G., R. Srinivasan, R. S. Muttiah, and J. R. Williams. 1998. Large area hydrologic modeling and assessment - Part 1: Model development. J. of the American Water Resources Association 34(1): 73-89.

Bagdon, J. K., S. Plotkin, and E. S. Hesketh. 1994. NAPRA technology transfer overview: Introduction. Washington, D.C.: USDA. 
Bakhsh, A., and R. S. Kanwar. 2001. Simulating tillage effects on nonpoint source pollution from agricultural lands using GLEAMS. Transactions of the ASAE 44(4): 891-898.

Boesch, D. F., R. B. Brinsfield, and R. E. Magnien. 2001. Chesapeake Bay eutrophication: scientific understanding, ecosystem restoration, and challenges for agriculture. J. of Environmental Quality 30(2): 303-320.

Brouder, S., B. Hofmann, E. Kladivko, R. Turco, A. Bongen, and J. Frankenberger. 2005. Interpreting nitrate concentration in tile drainage water. Agronomy Guide. Purdue Extension AY-318(W). West Lafayette, Ind.

Elliot, W. J., and C. D. Arnold. 2001. Validation of the weather generator CLIGEN with precipitation data from Uganda. Transactions of the ASAE 44(1): 53-58.

Gerwig, B. K., K. C. Stone, R. G. Williams, D. W. Watts, and J. M. Novak. 2001. Using GLEAMS and REMM to estimate nutrient movement from a spray field and through a riparian forest. Transactions of the ASAE 44(3): 505-512.

Hertel, T. W., K. Stiegert, and H. Vroomen. 1996. Nitrogen-land substitution in corn production: a reconciliation of aggregate and firm-level evidence. American J. of Agricultural Economics 78(1): 30-40.

Indiana Agricultural Statistics. 2000-2004. Crop and Weather Report. Available at: http://www.nass.usda.gov/in/cropweat/ cropweat.htm. Accessed 20 September 2005.

Khanna, M. 2001. Non-mandatory approaches to environmental protection. J. of Economic Surveys 15(3): 291-325.

Khanna, M., W. Yang, R. Farnsworth, and H. Onal. 2003. Targeting of CREP to improve water quality: Determining land rental offers with endogenous sediment deposition coefficients. American Journal of Agricultural Economics 85 (3): 538-553.

Kladivko, E. J., J. R. Frankenberger, D. B. Jaynes, D. W. Meek, B. J. Jenkinson, and N. R. Fausey. 2004. Nitrate leaching to subsurface drains as affected by drainage spacing and changes in crop production system. J. of Environmental Quality 33(5): 1803-1813.

Knisel, W. G., and F. M. Davis. 2000. Groundwater loading effects of agricultural management systems. Version 3.0. user manual. U.S. Department of Agriculture (USDA), Agricultural Research Service (ARS). Southeast Watershed Research Laboratory. Tifton, Georgia. SEWRL-WGK/FMD-050199.

Leonard, R. A., W. G. Knisel, and D. A. Still. 1987. GLEAMS: Groundwater loading effects of gricultural management systems. Transactions of the ASAE 30(5): 1403-1417.

Lim, K. J. 2001. Enhanced NAPRA WWW Spatial Decision Support System (SDSS) with river water quality modeling capability. PhD dissertation. West Lafayette, Ind.: Purdue University, Agricultural and Biological Engineering Department.

Lim, K. J., and B. A. Engel. 2003. Extension and enhancement of National Agricultural Pesticide Risk Analysis (NAPRA) WWW decision support system to include nutrients. Computers and Electronics in Agriculture 38(3): 227-236.

Mahmood, B., J. M. Russell, and G. L. Wall. 2002. Field-scale nitrate simulation. Transactions of the ASAE 45(6): 1835-1842.

Nicks, A.D., L. J. Lane, and G.A. Gander. 1995. Weather generator. Chapter 2 in USDA-Water Erosion Prediction Project: Hillslope Profile and Watershed Model Documentation. D.C. Flanagan and M. A. Nearing, eds. NSERL Report No. 10. West Lafayette, Ind.: USDA-ARS National Erosion Research Laboratory.

Nielson, R.L. 2005. Corn yield trends for Indiana: 1930 to 2005. Corny News Network. Available at: http://www.agry.purdue.edu/ext/corn/news/articles.05/CornYldT rend2005.html. Accessed 28 February 2006.
Power, J. F., R. Wiese, and D. Flowerday. 2001. Managing farming systems for nitrate control: a research review from management systems evaluation areas. J. of Environmental Quality 30(6): $1866-1880$

Randall, G. W., and J. Vetsch. 2005. Nitrate losses in subsurface drainage from a corn-soybean rotation as affected by fall and spring application of nitrogen and nitrapyrin. $J$. of Environmental Quality 34(2): 590-597.

Shirmohammadi, A., F. Djodjic, and L. Bergstrom. 2005. Scaling issues in sustainable management of nutrient losses. Soil Use and Management 21: 160-166.

Thomas, M. A. 2006. Evaluation of nutrient management plans using an integrated modeling approach. MS. thesis. West Lafayette, Ind.: Purdue University, Agricultural and Biological Engineering Department.

Tim, U. S. 1996. Coupling vadose zone models with GIS: emerging trends and potential bottlenecks. J. of Environmental Quality 25(3): 535-544.

USDA-ERS. 1990-1995. Cropping Practices Survey. Raw data. Washington, D.C.: U.S. Department of Agriculture (USDA), Economics and Statistics System. Available at: http://www.ers.usda.gov/data/archive/93018/. Accessed 27 June 2005.

USDA-NRCS. 1995. State Soil Geographic (STATSGO) Database: Data use information. Forth Worth, Tex.: U.S. Department of Agriculture, National Cartography and GIS Center.

USDA-NRCS. 2005. Environmental Quality Incentives Program (EQIP) national listening session transcript. Washington, D.C.: USDA-NRCS. Available at: http://www.nrcs.usda.gov/ programs/eqip/eqiplisteningsessiontranscript.html. Accessed 23 January 2006.

USDA-NRCS. 2006. Electronic Field Office Technical Guide. Washington, D.C.: USDA-NRCS. Available at: http://efotg.nrcs.usda.gov. Accessed 8 June 2006.

Vaché, K. B., M. Eilers, and M. Santelmann. 2002. Water quality modeling of alternative agricultural scenarios in the US Corn Belt. J. of the American Water Resources Association 38(3):773-787.

Vitosh, M. L., J. W. Johnson, and D. B. Mengel. 1995. Tri-state fertilizer recommendation for corn, soybeans, wheat and alfalfa. East Lansing, Mich.: Michigan State University Extension. Available at: http://www.ces.purdue.edu/extmedia/ AY/AY-9-32.pdf. E-2567: 9-13. Accessed 6 June 2005.

Walpole, R. E., R. H. Myers, and S. L. Myers. 1998. Nonparametric statistics. In Probability and Statistics for Engineering and Scientists, 609-665. New Jersey: Prentice Hall.

Williams, J. R., P. T. Dyke, W. W. Fuchs, V. W. Benson, O. W. Rice, and E. D. Taylor. 1990. EPIC-Erosion/Productivity Impact Calculator: 2. User Manual, eds. A. N. Sharpley and J. R. Williams. U.S. Department of Agriculture Technical Bulletin No. 1768. Temple, Tex.

Yang, W., M. Khanna, and R.L. Farnsworth. 2005. Effectiveness of conservation programs in Illinois and gains from targeting. American Journal of Agricultural Economics 87(5):1248-1255.

Yu, B. 2002. Using CLIGEN to generate RUSLE climatic inputs. Transactions of the ASAE 45(4): 993-1001.

Zhang, X. C., and J. D. Garbrecht. 2003. Evaluation of CLIGEN precipitation parameters and their implications on WEPP runoff and erosion prediction. Transactions of the ASAE 46(2): 311-320. 
